\title{
TRANSFERS OF POTASSIUM IN RENAL INSUFFICIENCY ${ }^{1}$
}

\author{
By J. RUSSELL ELKINTON,² ROEERT TARAIL, 3 AND JOHN P. PETERS
}

(From the Department of Internal Medicine, Yale University School of Medicine, and the Medical Service of the New Haven Hospital, New Haven)

(Received for publication August 16, 1948)

Elevation in concentration of serum potassium in patients with renal insufficiency has been observed many times but has been considered to be a relatively rare occurrence (1-3). Reports of abnormally low levels of serum potassium in this disorder have been extremely infrequent (4 8). Nevertheless, the occasional finding in such patients of disturbances in the exchanges of potassium, has directed interest toward the clinical significance of these abnormalities.

Winkler, Hoff and Smith were the first to recognize that the toxicity of a high concentration of potassium in serum and extracellular fluid is due to its effect on the conduction system of the heart. In animals rendered anuric by nephrectomy or by ureteral ligation, death regularly resulted from extracellular accumulation, to cardiotoxic levels, of potassium released from tissue cells $(9,10)$. Such accumulation was speeded by the administration of potassium (10) and retarded by depletion of potassium prior to the establishment of the anuria (11). The potassium content of tissue cells in anuric animals has been shown to vary (12), but experiments in cats indicated that the lethal factor was the elevation of extracellular potassium concentration, not a change in the potassium of the cells (13).

Intolerance of patients with severe renal disease to administered potassium has been recognized in the past (14) and was clearly demonstrated by Winkler, Hoff, and Smith (15). Slight elevations of the serum concentration were found in five of 12 patients studied, but no cardiotoxicity was revealed in electrocardiographic tracings. Since then definite, and possibly fatal, changes in cardiac conduction have been reported in such

1 Aided by a grant from the James Hudson Brown Memorial Fund of the Yale University School of Medicine.

2 Present address : Department of Medicine, Hospital of the University of Pennsylvania, Philadelphia.

${ }^{3}$ Life Insurance Medical Research Fellow. patients with high concentrations of serum potassium (16-18).

It is evident, therefore, that in renal insufficiency the concentration of potassium in extracellular fluid may rise, that a number of variables influence the occurrence and rate of such a rise, and that the rise may threaten the life of the patient. Death may also occur in the presence of a normal or low serum concentration and be due to causes quite unrelated to disturbances of potassium metabolism.

The study reported here is an attempt to determine more exactly the frequency of, and the physiological factors involved in, abnormal exchanges of potassium in patients with severe renal insufficiency. The data are presented from the standpoint that abnormality of the concentration of serum potassium in cases of renal insufficiency with reduced glomerular filtration is a function of extracellular fluid volume, intake and output of potassium, and its distribution between the extra- and intracellular phases.

\section{EXPERIMENTAL MATERIAL AND PROCEDURE}

During a period of nine months 51 patients had concentrations of blood non-protein nitrogen greater than $100 \mathrm{mg}$. per cent; in 26 of these patients one or more measurements were made of the concentration of serum potassium. These 26 patients constitute the clinical ma-

TABLE I

Distribution of abnormal concentrations of serum potassium in patients with renal insufficiency according to type of renal disease

\begin{tabular}{l|c|c|c|c|c}
\hline \hline \multicolumn{1}{c|}{ Diagnosis } & $\begin{array}{c}\text { Num- } \\
\text { ber of } \\
\text { cases }\end{array}$ & \multicolumn{3}{|c}{$\begin{array}{c}\text { Concentration of serum } \\
\text { potassium in m.eq. per liter }\end{array}$} \\
\cline { 2 - 6 } & & $<3.5$ & $3.5-5.5$ & $5.6-6.4$ & $>6.4$ \\
\hline $\begin{array}{l}\text { Nephrosclerosis } \\
\text { Lower nephron } \\
\text { nephrosis }\end{array}$ & 5 & 2 & 6 & 2 & 5 \\
$\begin{array}{l}\text { Pyelonephritis } \\
\text { Glomerulonephritis }\end{array}$ & 3 & 0 & 2 & 0 & 1 \\
Other & 2 & 0 & 1 & 2 & 1 \\
\hline \multicolumn{1}{c|}{ Total } & 7 & 1 & 4 & 3 & 3 \\
\hline
\end{tabular}


TABLE II

Patients with renal insufficiency on whom balance studies were made: External transfers of water, electrolytes, and nitrogen

\begin{tabular}{|c|c|c|c|c|c|c|c|c|c|c|c|c|c|c|c|c|}
\hline \multirow{2}{*}{ Pt.t† } & \multirow{2}{*}{ Period } & \multicolumn{6}{|c|}{ Intake } & \multicolumn{5}{|c|}{ Urine } & \multicolumn{4}{|c|}{ Balance* } \\
\hline & & $\mathrm{H}_{2} \mathrm{O}$ & $\mathrm{Cl}$ & $\mathrm{Na}$ & $\mathbf{K}$ & $\mathbf{N}$ & $\mathrm{CHO}$ & Vol. & $\mathrm{Cl}$ & $\mathrm{Na}$ & $\mathbf{K}$ & $\mathbf{N}$ & $\mathrm{Cl}$ & $\mathrm{Na}$ & $\mathbf{K}$ & $\mathbf{N}$ \\
\hline P. McG. & $\begin{array}{c}\text { dates } \\
12 / 24-25\end{array}$ & $\begin{array}{c}c c . \\
1275 \dagger\end{array}$ & $\begin{array}{r}\text { m.eq. } \\
265\end{array}$ & $\begin{array}{r}\text { m.eq. } \\
263\end{array}$ & $\begin{array}{c}\text { m.eq. } \\
15\end{array}$ & \begin{tabular}{|c|} 
grams \\
1.8
\end{tabular} & $\begin{array}{c}\text { grams } \\
45\end{array}$ & $\begin{array}{l}c c . \\
110\end{array}$ & $\begin{array}{c}\text { m.eq. } \\
2\end{array}$ & $\begin{array}{c}\text { m.eq. } \\
3\end{array}$ & $\begin{array}{c}\text { m.eq. } \\
6\end{array}$ & $\begin{array}{c}\text { grams } \\
0.6\end{array}$ & $\begin{array}{r}\text { m.eq. } \\
+\quad 255\end{array}$ & $\begin{array}{r}\text { m.eq. } \\
+252\end{array}$ & $\begin{array}{l}\text { m.eq. } \\
+\quad 10\end{array}$ & $\begin{array}{l}\text { grams } \\
+\quad 1.2\end{array}$ \\
\hline A. $M$. & \begin{tabular}{|l|}
$1 / 20-21$ \\
$1 / 21-22$ \\
$1 / 22-23$ \\
$1 / 23-24$
\end{tabular} & $\begin{array}{l}7000 \\
3250 \\
4250 \\
4550\end{array}$ & $\begin{array}{l}423 \\
102 \\
541 \\
387\end{array}$ & $\begin{array}{l}485 \\
380 \\
765 \\
611\end{array}$ & $\begin{array}{l}4 \\
1 \\
1 \\
1\end{array}$ & $\begin{array}{r}12.4 \\
2.8 \\
2.8 \\
2.8\end{array}$ & $\begin{array}{r}275 \\
225 \\
50 \\
150\end{array}$ & $\begin{array}{r} \pm 0 \\
270 \\
90 \\
100\end{array}$ & $\begin{array}{r}14 \\
11 \\
8\end{array}$ & $\begin{array}{l}16 \\
14 \\
10\end{array}$ & $\begin{array}{l}9 \\
4 \\
2\end{array}$ & $\begin{array}{l}0.9 \\
0.6 \\
0.4\end{array}$ & $\begin{array}{r}+420 \\
+\quad 86 \\
+\quad 528 \\
+\quad 377\end{array}$ & $\begin{array}{r}+481 \\
+\quad 361 \\
+\quad 748 \\
+\quad 598\end{array}$ & $\begin{array}{ll}+ & 4 \\
- & 8 \\
- & 3 \\
- & 1\end{array}$ & $\begin{array}{r}+12.4 \\
+\quad 1.9 \\
+2.2 \\
+2.4\end{array}$ \\
\hline C. $\mathrm{K}$. & $1 / 20-21$ & 3190 & 96 & 378 & 2 & 5.6 & 180 & 740 & 22 & 26 & 25 & 3.6 & +70 & +346 & -23 & +2.0 \\
\hline W. M. & \begin{tabular}{|l|}
$12 / 13-16$ \\
$12 / 16-19$
\end{tabular} & $\begin{array}{l}8000 \ddagger \\
4500 \ddagger\end{array}$ & 77 & 113 & & & $\begin{array}{l}500 \\
250\end{array}$ & $\begin{array}{r}597 \\
2805\end{array}$ & $\begin{array}{r}28 \\
180\end{array}$ & $\begin{array}{r}38 \\
224\end{array}$ & $\begin{array}{l}11 \\
43\end{array}$ & $\begin{array}{l}2.1 \\
9.3\end{array}$ & $\begin{array}{l}+\quad 44 \\
-\quad 184\end{array}$ & $\begin{array}{l}+\quad 66 \\
-\quad 231\end{array}$ & $\begin{array}{l}-11 \\
-43\end{array}$ & $\begin{array}{l}-2.1 \\
-9.3\end{array}$ \\
\hline W. S. & $\begin{array}{l}2 / 11-14 \\
2 / 14-16 \\
2 / 16-17 \\
2 / 17-18 \\
2 / 18-19\end{array}$ & $\begin{array}{l}7620 \\
6170 \dagger \\
2500 \\
1500 \\
1500\end{array}$ & $\begin{array}{r}1474 \\
140 \\
36 \\
0 \\
0\end{array}$ & $\begin{array}{r}1605 \\
185 \\
0 \\
0 \\
0\end{array}$ & $\begin{array}{r}2 \\
29 \\
0 \\
0 \\
0\end{array}$ & $\begin{array}{l}5.6 \\
4.5 \\
0 \\
0 \\
0\end{array}$ & $\begin{array}{r}320 \\
155 \\
200 \\
75 \\
150\end{array}$ & $\begin{array}{r}2580 \\
885 \\
375 \\
200 \\
986\end{array}$ & $\begin{array}{r}26 \\
33 \\
6 \\
6 \\
15\end{array}$ & $\begin{array}{r}36 \\
32 \\
5 \\
5 \\
11\end{array}$ & $\begin{array}{r}102 \\
33 \\
17 \\
17 \\
47\end{array}$ & $\begin{array}{r}17.4 \\
5.9 \\
2.6 \\
2.6 \\
6.5\end{array}$ & $\begin{array}{r}+1442 \\
+\quad 105 \\
+\quad 28 \\
+\quad 8 \\
-\quad 17\end{array}$ & $\begin{array}{rr}+ & 1560 \\
+ & 161 \\
- & 8 \\
- & 8 \\
- & 14\end{array}$ & $\begin{array}{lr}-100 \\
-\quad 4 \\
-\quad 17 \\
-\quad 17 \\
-\quad 47\end{array}$ & $\begin{array}{l}-11.8 \\
-\quad 1.4 \\
=2.6 \\
=2.6 \\
-6.5\end{array}$ \\
\hline P. DeB. & $\begin{array}{l}2 / 28-3 / 1 \\
3 / 1-2 \\
3 / 2-3 \\
3 / 3-4 \\
3 / 4-5 \\
3 / 5-6\end{array}$ & $\begin{array}{r}1800 \dagger \\
5600 \dagger \\
700 \dagger \\
1900 \dagger \\
2000 \dagger \\
1170 \dagger\end{array}$ & $\begin{array}{r}17 \\
12 \\
274 \\
8 \\
12 \\
24\end{array}$ & $\begin{array}{r}48 \\
221 \\
307 \\
40 \\
48 \\
58\end{array}$ & $\begin{array}{l}42 \\
16 \\
17 \\
20 \\
43 \\
16\end{array}$ & $\begin{array}{r}21.1 \\
24.2 \\
17.1 \\
14.1 \\
21.6 \\
8.2\end{array}$ & $\begin{array}{r}160 \\
170 \\
70 \\
110 \\
200 \\
120\end{array}$ & $\begin{array}{r}350 \S \\
20 \\
20 \\
0 \\
0 \\
25\end{array}$ & 든 & $\frac{14}{-}$ & $\frac{18}{-}$ & $\begin{array}{l}5.9 \\
-\end{array}$ & $\begin{array}{lr}- & 1 \\
+ & 7 \\
+ & 266 \\
+ & 4 \\
+ & 8 \\
+ & 21\end{array}$ & $\begin{array}{rr}+ & 30 \\
+ & 213 \\
+ & 295 \\
+ & 34 \\
+ & 42 \\
+ & 53\end{array}$ & $\begin{array}{l}+24 \\
+\quad 16 \\
+\quad 17 \\
+\quad 20 \\
+\quad 43 \\
+\quad 15\end{array}$ & $\begin{array}{l}+15.2 \\
+24.2 \\
+17.1 \\
+14.1 \\
+21.6 \\
+8.2\end{array}$ \\
\hline L. T. & $1 / 6-7$ & 2000 & 25 & 35 & 2 & 2.8 & 75 & 95 & 4 & 4 & 3 & 0.7 & $-57^{* *}$ & $-\quad 18$ & -9 & +0.5 \\
\hline R. S. & $11 / 4-8$ & 1000 & 0 & 0 & 0 & 0 & 0 & 0 & & & & & & & & \\
\hline J. P. & $\begin{array}{l}4 / 14-15 \\
4 / 15-16 \\
4 / 16-16\end{array}$ & $\begin{array}{l}3000 \dagger \\
2440 \dagger \\
2000 \dagger\end{array}$ & $\begin{array}{r}55 \\
196 \\
6\end{array}$ & $\begin{array}{r}61 \\
190 \\
6\end{array}$ & $\begin{array}{r}15 \\
53 \\
2\end{array}$ & \begin{tabular}{r|}
2.9 \\
19.0 \\
0.1
\end{tabular} & $\begin{array}{l}150 \\
211 \\
150\end{array}$ & $\begin{array}{r}0 \\
250 \\
0\end{array}$ & 9 & & 9 & 2.3 & $\begin{array}{rr}+ & 53 \\
+\quad 182 \\
+\quad 1\end{array}$ & $\begin{array}{r}+\quad 58 \\
-\quad 1\end{array}$ & $\begin{array}{r}+\quad 15 \\
+\quad 44 \\
+\quad 2\end{array}$ & $\begin{array}{r}+2.9 \\
+16.7 \\
+\quad 0.1\end{array}$ \\
\hline F. S. & $\begin{array}{l}3 / 20-21 \\
3 / 21-22 \\
3 / 22-23\end{array}$ & $\begin{array}{l}2000 \\
2750 \\
2400\end{array}$ & $\begin{array}{r}96 \\
212 \\
253\end{array}$ & $\begin{array}{l}127 \\
243 \\
204\end{array}$ & $\begin{array}{r}2 \\
2 \\
82\end{array}$ & $\begin{array}{l}6.2 \\
6.2 \\
6.2\end{array}$ & $\begin{array}{r}100 \\
75 \\
100\end{array}$ & $\begin{array}{l}2200 \\
1400 \\
1550\end{array}$ & $\begin{array}{l}87 \\
58 \\
84\end{array}$ & $\begin{array}{r}148 \\
89 \\
104\end{array}$ & $\begin{array}{l}18 \\
10 \\
25\end{array}$ & $\begin{array}{l}4.4 \\
3.1 \\
6.1\end{array}$ & $\begin{array}{rr}+\quad 7 \\
+\quad 152 \\
+\quad 162\end{array}$ & $\begin{array}{rr}-\quad 24 \\
+\quad 151 \\
+\quad 89\end{array}$ & $\begin{array}{rr}- & 16 \\
- & 8 \\
+\quad 57\end{array}$ & $\begin{array}{l}+1.8 \\
+3.1 \\
+0.1\end{array}$ \\
\hline
\end{tabular}

* Balances of $\mathrm{Cl}$ and $\mathrm{Na}$ corrected for small quantities lost in serum drawn for analysis.

$\dagger$ Includes small quantities taken orally, the contents of which were estimated from Sherman's tables (43).

† Includes oral liquids in small quantities, which probably contained only small amounts of electrolyte and nitrogen. Includes stool, $75 \mathrm{cc}$. urine, and $100 \mathrm{cc}$. vomitus.

** Balances include $550 \mathrm{cc}$. of vomitus, which contained $75 \mathrm{~m} . e q . \mathrm{Cl}, 45 \mathrm{~m} . e q$. of $\mathrm{Na}, 8 \mathrm{~m} . e q$. of $\mathrm{K}$, and 1.6 grams of $\mathrm{N}$. t† Diagnoses are indicated in Table IV.

terial for the survey. They are a selected group in that potassium determinations were more frequently done in patients who were oliguric and in patients who were on the medical service. The concentration of serum potassium was followed with varying frequency and in variable proximity to the time of death. There were many types of kidney disorders responsible for the renal insufficiency in these patients; the diagnoses were made from clinical data, and from necropsy findings when available.

Ten of the 26 patients were studied more intensively. During periods which varied from 12 hours to eight days, exchanges of chloride, sodium, potassium, and nitrogen were measured and the transfers of potassium between the various phases of body fluid were calculated. In some, the volume of distribution and clearance of manni- tol were determined, to approximate the volume of extracellular fluid and the glomerular filtration rate (19). Electrocardiograms were taken simultaneously with many of the determinations of serum potassium.

The chemical methods and mode of calculation have been detailed in previous communications (20-22).

\section{RESULTS}

The analytical and derived data are presented in Tables I-V and in Figures 1 and 2.

The concentration of serum potassium was greater than 5.5 m.eq. per liter in more than one-half the cases; abnormal concentrations were not exclusively associated with any one kind of 
renal lesion (Tables I, III). In 11 of the 26 patients it was greater than 6.4 m.eq. per liter, the concentration just above which electrocardiographic changes attributable to the concentration of serum potassium sometimes appeared (23). Abnormally low concentrations were much less frequent, being found in only 4 of the 26 patients.

In most of the patients the concentration of serum potassium rose as the renal insufficiency progressed (Table III). Distinct decline of serum potassium, as death approached, occurred in at least one patient. In 18 patients concentrations of serum potassium were measured less than 24 hours before death; of these 12 were elevated, four were normal, and two were low. In certain patients changes in the concentrations of blood non-protein nitrogen and of serum potassium varied in similar directions (Table III), but for the group as a whole there was a wide variation between any given level of potassium and any given level of non-protein nitrogen.

Oliguria or anuria appeared to be a prerequisite to elevation of the serum concentration. None of the patients with concentrations of serum potassium above 6.6 m.eq. per liter produced more than $250 \mathrm{cc}$. of urine during the preceding 24 hours (Figure 1). On the other hand, periods of anuria or oliguria were not necessarily followed by elevation of serum potassium.

The factors which determine a given concentration of potassium in serum are the volume of extracellular fluid and the amount of extracellular potassium which results from exchanges with the cells on the one hand and the external environment on the other. These exchanges were calculated in detail from the balance data obtained in 10 patients (Tables II and III), and are summarized for nine patients in terms of average

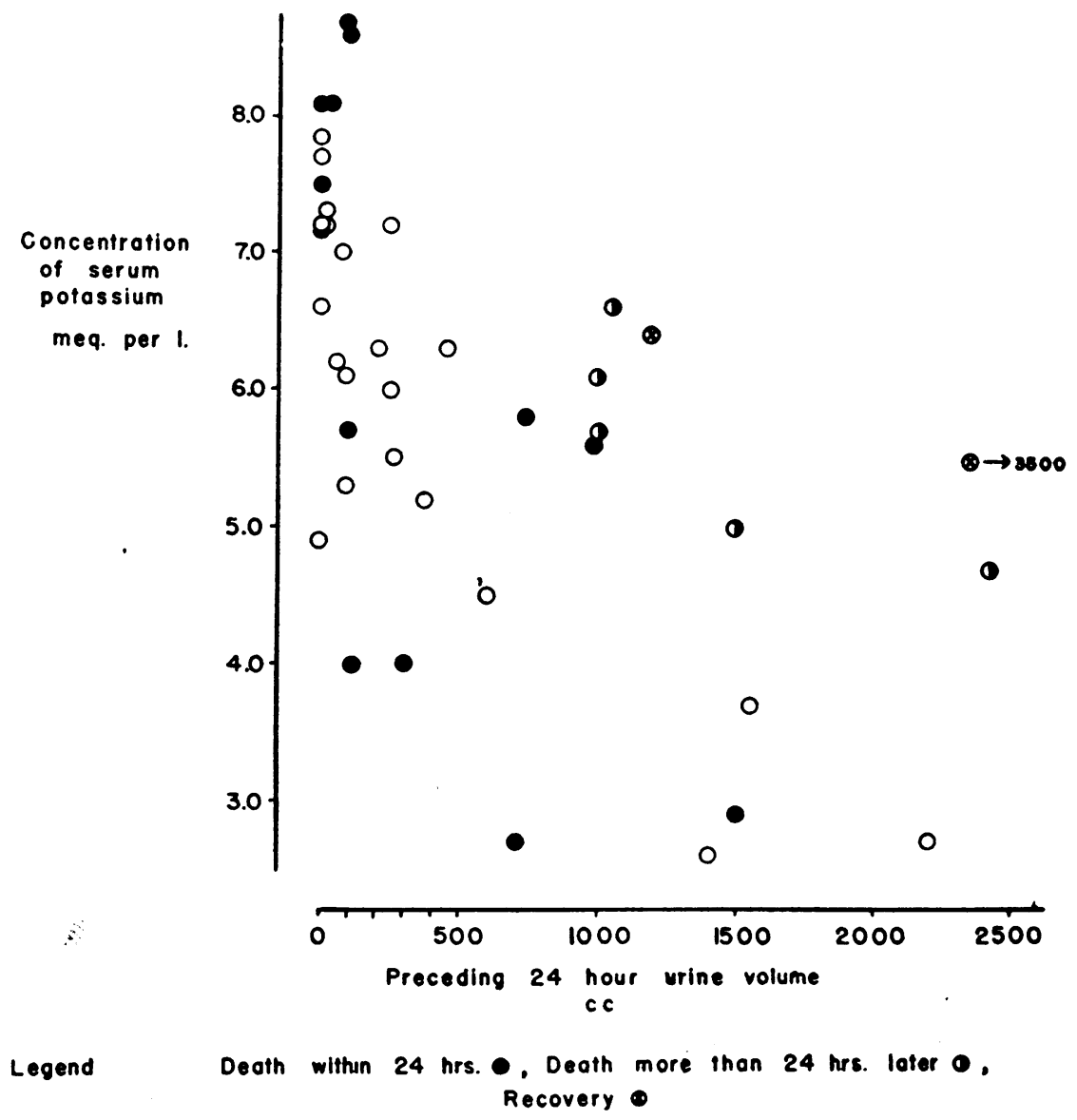

Fig. 1. The Relation of the Concentration of Serum Potassium to Urine VOLUME 
daily values in Table IV. In most of the patients the volume of extracellular fluid expanded. Although the rate of expansion varied considerably, it may have ameliorated any rise in potassium concentration which would have resulted from accumulation of the ion in that fluid phase. In three of the five patients in whom the final concentration of serum potassium was greater than 7.4 m.eq. per liter, the small amount of potassium ingested in food exceeded the urinary output, and the difference, or positive balance, was equal to part or all of the increase in extracellular potassium. In all of the four patients whose final concentrations of serum potassium were less than $6.5 \mathrm{~m}$.eq. per liter, the intake of potassium was negligible and the patients were in negative balance with respect to the ion. A net transfer of potassium from cellular to extracellular phase took place in most of the cases; only in two patients did the cells take up potassium. In four cases in which the ion accumulated in the extracellular phase, the cellular decrement was at least as great as the extracellular increment. If the transfers of intracellular potassium are arbitrarily subdivided into those which move with nitrogen according to cell anabolism or catabolism, and those which enter or leave intact cells, the data indicate that in only two cases did part or all of the potassium from catabolized cells enter intact cells. The storage of potassium by the cells did not appear to be directly correlated with the in- take of carbohydrate or insulin (Tables II, IV).

Electrocardiograms were obtained from four patients when the serum potassium was greater than 7.4 m.eq. per liter (23). All showed toxic effects of potassium. These patients died suddenly. In one patient, P. DeB., an electrocardiogram was obtained within a few seconds of death. This tracing showed widespread disorganization and prolongation of the QRS complex. Although the concentration of serum potassium was 8.1 m.eq. per liter, it is impossible to assert that it was responsible for the cardiac arrest, as other factors probably play a role in the death of these patients. Other signs and symptoms that have been reported as evidence of potassium intoxication were not observed.

The primary disturbance in these patients was the inability of the kidney to excrete potassium. In comparison with previously reported subjects with normal kidneys, and whose intake of potassium was low (22), the rate of excretion of potassium was lower and the urine:plasma concentration ratio (U/P) was about the same (Figure 2). The rate of excretion and the concentration ratio of potassium were reduced in patients with renal insufficiency when contrasted to normal subjects on an intake high in potassium. Nevertheless, even this limited excretory ability sufficed to prevent an accumulation of potassium in the extracellular fluid when the intake of potas-
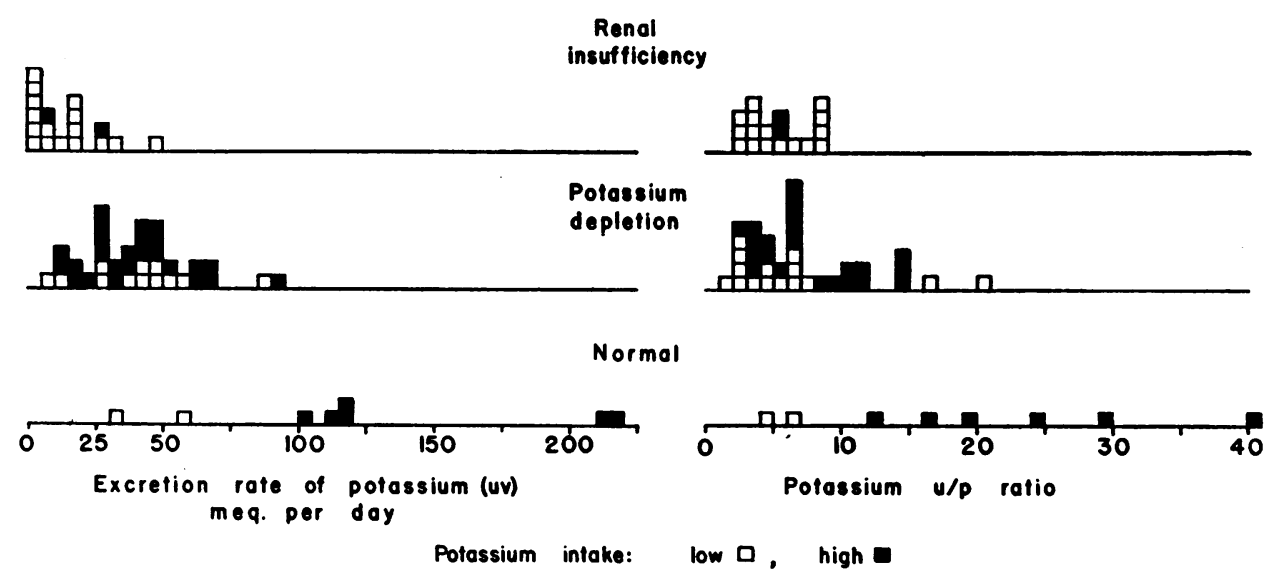

Fig. 2. The Excretion Rate and Concentration Ratio of Potassium in Subjects with Renal Insufficiency and in Those with Normal Kidneys with and without Potassium Depletion

Each square indicates one subject period. 
J. RUSSEll ElKinton, ROBERT TARAIL, AND JOHN P. PETERS

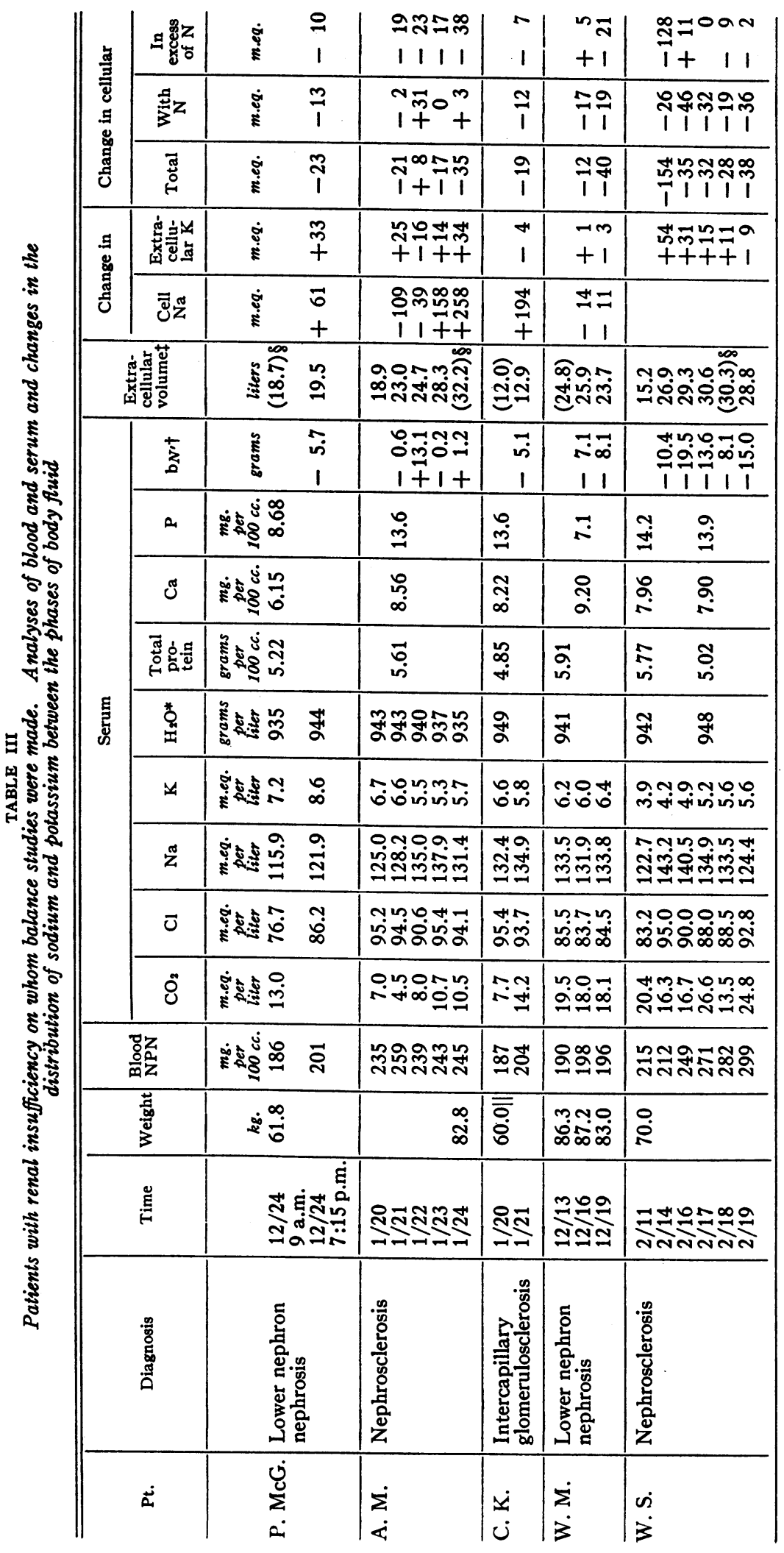




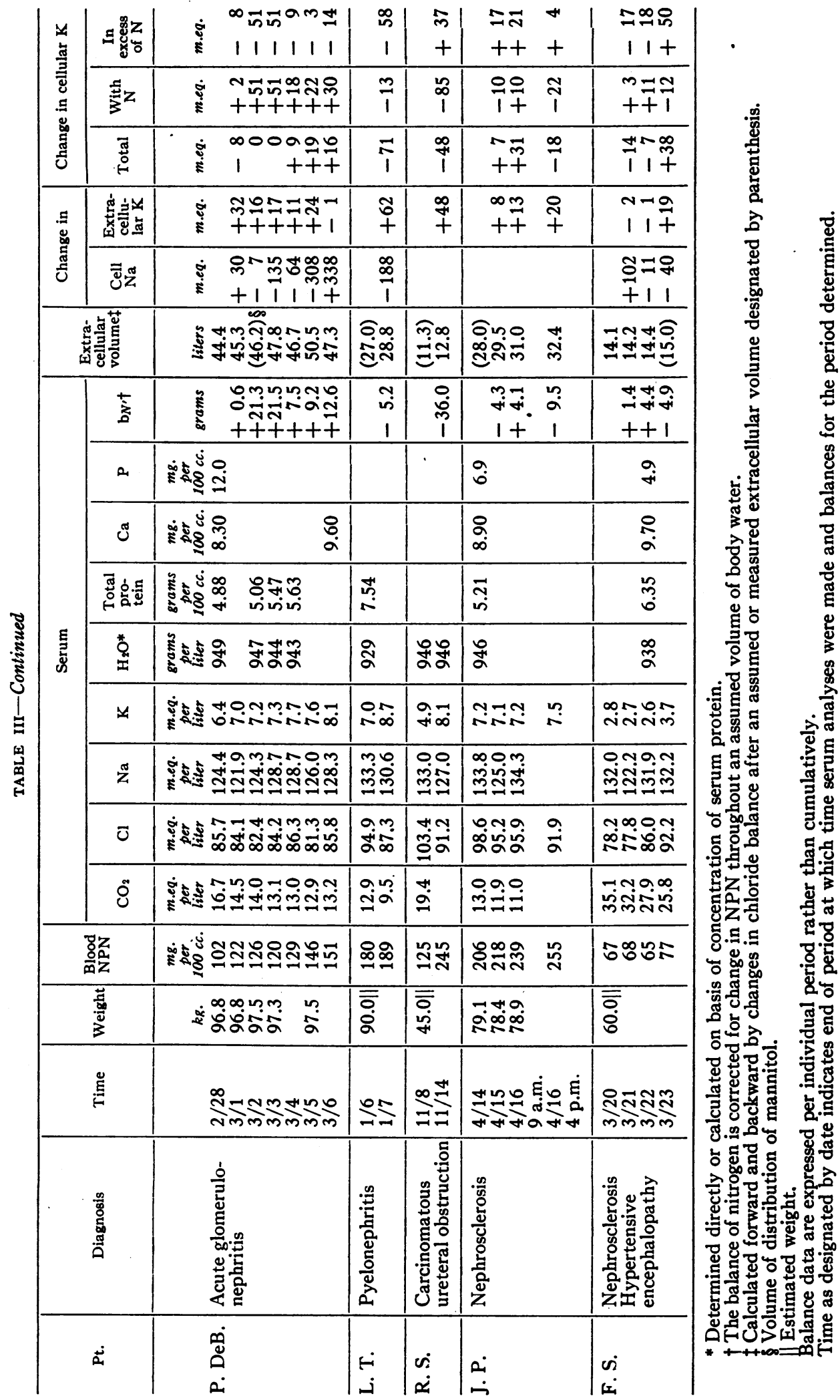


TABLE IV

Transfers of potassium in patients with renal insufficiency

\begin{tabular}{|c|c|c|c|c|c|c|c|c|c|c|c|c|}
\hline \multirow{3}{*}{ Patient } & \multirow{3}{*}{ Period } & \multicolumn{2}{|c|}{ Final serum $\mathbf{K}$} & \multicolumn{9}{|c|}{ Average daily } \\
\hline & & \multirow{2}{*}{ Conc. } & \multirow{2}{*}{$\begin{array}{l}\text { Time } \\
\text { before } \\
\text { death }\end{array}$} & \multirow{2}{*}{$\begin{array}{l}\text { Carbo- } \\
\text { hydrate } \\
\text { intake }\end{array}$} & \multirow{2}{*}{$\underset{\text { intake }}{\mathbf{K}}$} & \multirow{2}{*}{$\underset{\text { output }}{\mathbf{K}}$} & \multirow{2}{*}{$\begin{array}{l}\text { Urine } \\
\text { vol. }\end{array}$} & \multicolumn{2}{|c|}{$\begin{array}{l}\text { Change in } \\
\text { extracellular }\end{array}$} & \multicolumn{3}{|c|}{$\begin{array}{l}\text { Change in } \\
\text { intracellular } \mathrm{K}\end{array}$} \\
\hline & & & & & & & & Vol. & $\mathbf{K}$ & Total & With $\mathrm{N}$ & Excess \\
\hline $\begin{array}{l}\text { P. McG. } \\
\text { A. M. } \\
\text { C. K. } \\
\text { W. M.t } \\
\text { W. S. } \\
\text { P. DeB. } \\
\text { L. T. } \\
\text { R. S. } \\
\text { J. P. }\end{array}$ & $\begin{array}{l}\text { days } \\
\frac{1}{2} \\
4 \\
1 \\
6 \\
8 \\
7 \\
1 \\
6 \\
2.3\end{array}$ & $\begin{array}{c}\text { m.eq. } \\
\text { per liter } \\
8.6 \\
5.7 \\
5.8 \\
6.4 \\
6.0 \\
8.1 \\
8.7 \\
8.1 \\
7.5\end{array}$ & $\begin{array}{r}\text { hours } \\
6 \\
20 \\
<24 \\
>24 \\
<24 \\
0 \\
0 \\
3 \\
15\end{array}$ & $\begin{array}{c}\text { grams } \\
90 \\
175 \\
180 \\
146 \\
119 \ddagger \\
119 \ddagger \\
75 \\
0 \\
236 \neq\end{array}$ & $\begin{array}{r}\text { m.eq. } \\
30 \\
2 \\
2 \\
0 \\
4 \\
22 \\
2 \\
0 \\
30\end{array}$ & $\begin{array}{l}m . e q . \\
12 \\
4 \\
25 \\
9 \\
27 \\
3 \\
11 \\
0 \\
4\end{array}$ & $\begin{array}{r}c c . \\
330 \\
115 \\
110 \\
561 \\
629 \\
13 \\
95 \\
0 \\
109\end{array}$ & $\begin{array}{c}\text { liters } \\
1.6^{*} \\
3.3 \\
0.9 \\
-0.2 \\
1.7^{*} \\
0.4^{*} \\
1.8 \\
0.3 \\
1.8\end{array}$ & $\begin{array}{l}\text { m.eq. } \\
+64 \\
+14 \\
+4 \\
0 \\
+13 \\
+14 \\
+62 \\
+8 \\
+18\end{array}$ & $\begin{array}{l}\text { m.eq. } \\
-46 \\
-16 \\
-19 \\
-9 \\
-36 \\
+5 \\
-71 \\
-8 \\
+9\end{array}$ & $\begin{array}{l}\text { m.eq. } \\
-28 \\
+8 \\
-12 \\
-6 \\
-20 \\
+25 \\
-13 \\
-14 \\
-9\end{array}$ & $\begin{array}{l}\text { m.eq. } \\
-18 \\
-24 \\
-7 \\
-3 \\
-16 \\
-20 \\
-58 \\
+6 \\
+18\end{array}$ \\
\hline
\end{tabular}

* Calculated by $\mathrm{Cl}$ balance from mannitol space.

† Recovered. $\ddagger$ Insulin given.

sium was restricted and the oliguria was not extreme.

The rate of glomerular filtration of potassium was reduced far out of proportion to its rate of excretion in two of the three patients in whom the clearance of mannitol was measured. These data, which are presented in Table $\mathrm{V}$ with similar data from the control subjects with normal kidneys, permit a distinction between disturbances of glomerular and of tubular function. In these two patients the rate of excretion approached, if it did not exceed, the rate of filtration. The error is so great that this cannot be interpreted as definite evidence of tubular secretion. Nevertheless, the ratio of potassium excreted to that filtered certainly exceeded any such ratios in the control subjects. This was so to a lesser degree with respect to water. Defective glomerular filtration appeared to be the principal factor limiting the excretion of potassium.

The exchanges of potassium were studied in one patient with renal insufficiency with a low concentration of serum potassium (F. S., Tables II and III). During the first day of study sodium was wasted in the urine; the rate of excretion of potassium was within the range found in the potassium-deficient patients with normal kidneys. Since the glomerular filtration rate was probably markedly reduced in this patient the normal excretory rate may have been the result of proportionately decreased tubular reabsorption. Subse- quently, when potassium was administered it entered the cells and was retained.

\section{DISCUSSION}

The results of this study indicate that elevations in the concentration of serum potassium are not infrequent in patients with renal insufficiency. Given the primary difficulty of inadequate renal excretion of potassium, the presence and degree of a rise in the extracellular concentration of the ion depends upon the change in volume of the extracellular fluid, intake of potassium, extrarenal loss of potassium, and net transfer of potassium between the extracellular fluid and the cells. In patients who are anuric and who are receiving parenteral fluids, the extracellular volume may expand. Such a change does not necessarily lower the potassium concentration since it has been shown in experimental animals that expansion of the extracellular volume in itself may lead to transfer of some potassium from the cells (24). Intake of potassium is an important factor in the accumulation of extracellular potassium as the intake readily may exceed the output or rate of excretion. To a certain extent patients are protected against the ingestion of potassium by anorexia, nausea, and pylorospasm (15). But the administration of potassium by any route may jeopardize life, and is clearly contraindicated in any patient with anuria or oliguria.

Extra-renal losses of potassium in gastrointestinal fluid may modify to a limited extent the 
extracellular concentration of the ion. But this concentration is probably determined in the main by exchanges of potassium between the extracellular fluid and the cells. In agreement with other observers $(25,26)$ release of potassium from cells as an agonal or terminal phenomenon due to anoxia, could not be the explanation of the elevated concentration of serum potassium in most of our cases because the rate of rise was not accelerated. On the other hand, potassium was taken up and retained in the cellular phase in only a few of our cases with high extracellular concentrations. This is surprising, since in normal dogs large amounts of potassium can enter cells before being excreted (27), and since others have observed anuric patients to maintain a concentration of serum potassium within the normal range over many days (28). However, these transfers are closely related to the processes of cellular metabolism and in these patients not all of the metabolic variables were known. This fact makes it difficult to predict in a given case the net result of exchanges of potassium between the two fluid phases. The deficit of potassium present in the patients with low serum potassium and renal insufficiency probably resulted from losses of the ion in urine and in gastrointestinal fluid analogous to those observed in potassium depletion associated with normal renal function (22).
There was diminution in the concentration and excretion of potassium by the kidney in the present group of patients. This finding is in agreement with Winkler, Hoff, and Smith (15) and with Keith and Osterberg (29), who found that the clearance of potassium was low in such patients even when potassium was administered.

The rate of glomerular filtration was greatly depressed. In the organism with normal kidneys tubular reabsorption of potassium appears to be, within limits, independent of that of water. During water deprivation the concentration of potassium in urine of the dog may rise to 500 m.eq. per liter, representing a $\mathrm{U} / \mathrm{P}$ ratio of 80 (30). Increased concentration ratios of lesser magnitude may be inferred from similar experiments on man (31). During water diuresis the excretion rate of potassium may be unaltered and the $U / P$ ratio falls to 1.0 (32). To our knowledge, no $U / P$ ratio of less than 1.0 has been reported (22). When the concentration ratio of potassium exceeds 1.0 , it implies that the concentration of potassium in the reabsorbate is less than that of serum. If the concentration ratio of potassium were less than 1.0, the concentration of potassium in the reabsorbate would be greater than that of serum. Tubular secretion of potassium appears to have been demonstrated by Berliner (33) and by Gilman and Mudge (34) under certain experimental circum-

TABLE $v$

Factors in the renal excretion of potassium

\begin{tabular}{|c|c|c|c|c|c|c|c|c|c|c|}
\hline \multirow[b]{2}{*}{ Clinical group } & \multirow[b]{2}{*}{ Subject } & \multirow{2}{*}{$\begin{array}{c}\text { Urine } \\
\text { volume } \\
V=\mathrm{H}_{2} \mathrm{O}^{\circ}\end{array}$} & \multirow{2}{*}{$\begin{array}{c}\text { Mannitol } \\
\text { clearance } \\
=\mathrm{H}_{2} \mathrm{O}_{f}\end{array}$} & \multicolumn{5}{|c|}{ Potassium } & \multirow[b]{2}{*}{$\frac{K_{\mathbf{g}}}{\bar{K}_{f}}$} & \multirow[b]{2}{*}{$\frac{\mathrm{H}_{2} \mathrm{O}_{6}}{\mathrm{H}_{2} \mathrm{O}_{f}}$} \\
\hline & & & & Intake & $\begin{array}{l}\text { Aver. } \\
\text { serum } \\
\text { conc. } P\end{array}$ & $\frac{U}{P}$ & $\begin{array}{c}\text { Excretion } \\
\text { rate } \\
U V=K\end{array}$ & $\underset{\substack{\text { Fate } \\
\boldsymbol{K}}}{\text { Filtration }}$ & & \\
\hline Normal & R. E. & $\begin{array}{c}\text { ml. per } \\
\text { day } \\
1710 \\
1860\end{array}$ & $\begin{array}{c}\text { ml. per } \\
\text { min. } \\
90^{*} \\
90^{*}\end{array}$ & $\begin{array}{c}\text { m.eq. per } \\
\text { day } \\
250 \\
2\end{array}$ & $\begin{array}{c}\text { m.eq. per } \\
\text { liter } \\
4.3 \\
3.7\end{array}$ & $\begin{array}{r}29.7 \\
4.9\end{array}$ & $\begin{array}{c}\text { m.eq. per } \\
\text { day } \\
218 \\
34\end{array}$ & $\begin{array}{c}\text { m.eq. per } \\
\text { day } \\
558 \\
480\end{array}$ & $\begin{array}{l}0.39 \\
0.07\end{array}$ & $\begin{array}{l}0.01 \\
0.01\end{array}$ \\
\hline \multirow{2}{*}{$\begin{array}{c}\text { Potassium } \\
\text { depleted, } \\
\text { normal } \\
\text { kidneys }\end{array}$} & E. R. & $\begin{array}{l}3420 \\
2030\end{array}$ & $\begin{array}{l}111^{*} \\
111\end{array}$ & $\begin{array}{r}0 \\
88\end{array}$ & $\begin{array}{l}2.5 \\
2.45\end{array}$ & $\begin{array}{l}6.9 \\
3.0\end{array}$ & $\begin{array}{l}59 \\
15\end{array}$ & $\begin{array}{l}400 \\
392\end{array}$ & $\begin{array}{l}0.15 \\
0.04\end{array}$ & $\begin{array}{l}0.02 \\
0.01\end{array}$ \\
\hline & R. W. & $\begin{array}{r}1385 \\
830\end{array}$ & - & $\begin{array}{r}2 \\
109\end{array}$ & $\begin{array}{l}3.85 \\
4.0\end{array}$ & $\begin{array}{l}1.0 \\
3.0\end{array}$ & $\begin{array}{l}55 \\
10\end{array}$ & - & 二 & - $=$ \\
\hline \multirow{3}{*}{$\begin{array}{l}\text { Renal insuffi- } \\
\text { ciency }\end{array}$} & W. S. & 986 & 3.1 & 0 & 5.6 & 8.5 & 47 & 25 & 1.88 & 0.22 \\
\hline & P. McG. & $110 \dagger$ & 0.7 & ot & 7.5 & 6.8 & $5.6 t$ & $5.2 \dagger$ & 1.08 & 0.16 \\
\hline & A. M. & 100 & 2.8 & 1 & 5.5 & 4.4 & 2.4 & 22 & 0.11 & 0.02 \\
\hline
\end{tabular}

* Assumed to equal earlier or later determination.

$\dagger$ Per 16.5 hours. 
stances. The present data are inconclusive with respect to evidence of tubular secretion.

As predicted by Winkler et al. (15), elevation of the concentration of serum potassium was always preceded by oliguria or anuria in our patients. Instances of elevation of serum potassium to toxic levels have been reported in patients who were not oliguric (17), but these patients had received exogenous potassium. In two of the three patients in whom the rate of glomerular filtration was measured, the water excreted was an abnormally large portion of the water filtered, and the potassium excreted approached if it did not exceed the potassium filtered. The restricted excretion of potassium appeared to depend on the reduction of the quantity of potassium filtered. The increase in the ratio of potassium excreted to that filtered proportionately increased the loss of potassium in the urine.

Since depression of the rate of glomerular filtration appears to be the principal limiting factor with respect to potassium in renal insufficiency, the diminished tolerance for administered potassium by such patients is readily explained. The glomerular filtration rate in advanced renal insufficiency may be $10 \mathrm{cc}$. or less per minute (35); given a normal range of concentration of serum potassium, no more than 50 to 80 m.eq. are filtered per day. Excluding cellular uptake or extra-renal loss of administered potassium, the daily increment of extracellular potassium provided by a normal diet may exceed the amount of potassium filtered. If no potassium is ingested the increment of extracellular potassium due to release of the ion from the cellular phase may not greatly exceed that which can be filtered and excreted.

Aside from restriction of intake of potassium, the treatment of hyperkaliemia in the oliguric or anuric patient logically includes measures to counteract its physiological effect, to promote the transfer of potassium into cells, and to produce extra-renal excretion of potassium. The administration of calcium has been shown to antagonize the toxic action of potassium in dogs given infusions of potassium (36). The use of calcium for this purpose in man has been followed by changes in the electrocardiogram $(17,25)$ but has not yet been thoroughly evaluated. The administration of glucose and insulin to enhance the transfer of potassium into cells was attended with some success in cases of hyperkaliemia due to ischemic muscle necrosis (37). Apparent antagonism of the toxic action of potassium by the administration of glucose and calcium to an infant suffering from potassium intoxication has been reported (38). Glucose and insulin produced no significant effect in our patients, but was not given a sufficiently thorough and systematic trial. Infusion of hypertonic solution of sodium chloride, proposed on the theory that a low concentration of sodium in extracellular fluid leads to shift of potassium from cells, has been reported to produce electrocardiographic and clinical improvement (17). No such relationship is apparent in our data, and the use of hypertonic saline in one case was ineffectual ( $P$. McG.). Treatment with adrenocortical substances has not been successful in animals in which treatment was begun after anuria had been produced (39). Finally, a variety of measures have been proposed to effect the extra-renal removal of extracellular potassium. Dialyses by the artificial kidney of Kolff (40), by peritoneal lavage (41), and by small intestinal lavage (42), have been shown to lower the concentration of certain constituents of blood and serum and may lower that of potassium. These are fairly elaborate procedures, but may prove to have a useful role in combatting potassium intoxication in anuric patients with potentially reversible renal lesions. Such procedures, however, may be secondary in importance to the fundamental therapy of maintenance of volume and composition of the body fluids and of the integrity of the circulation.

\section{SUM MARY}

Changes in the concentration of serum potassium were studied in 26 patients with severe renal insufficiency. The serum potassium level was abnormally high in more than one-half of the $26 \mathrm{pa}$ tients. The greatest elevations were associated with oliguria; but oliguria was not always followed by an elevation in concentration of the ion.

In 10 of the patients the intake and excretion of potassium were measured and the distribution of the ion between the cells and extracellular fluid was calculated.

The principal limiting factor in the excretion of potassium was reduction in the glomerular filtration rate. 
The serum potassium was depressed in four of the cases; in the one in which it was studied the rate of renal excretion was not abnormally increased.

Potassium was taken up by the cells in only two of the nine cases with hyperkaliemia; this process was not clearly accelerated by the administration of carbohydrate and insulin.

Electrocardiographic evidence of intoxication occurred before death in the four patients with serum potassium greater than 7.4 m.eq. per liter.

\section{BIBLIOGRAPHY}

1. Rabinowitch, I. M., On the relative proportions of sodium, potassium, calcium, and magnesium in blood plasma in renal disease. J. Biol. Chem., 1924, 62, 667.

2. Hoffman, W. S., and Jacobs, H. R. D., The partition of potassium between the serum and corpuscles in health and disease. J. Lab. \& Clin. Med., 1934, 19, 633.

3. Keith, N. M., and Burchell, H. B., Potassium intoxication in uremia. Federation Proc., 1947, 6, 343.

4. Brown, M. R., Currens, J. H., and Marchand, J. F., Muscular paralysis and electrocardiographic abnormalities resulting from potassium loss in chronic nephritis. J. A. M. A., 1944, 124, 545.

5. Albright, F., and others, Osteomalacia and late rickets. Medicine, 1946, 25, 399.

6. Bywaters, E. G. L., and Stead, J. K., Thrombosis of the femoral artery with myohemoglobinuria and low serum potassium concentration. Clin. Sc., 1945, 5, 195.

7. Snapper, I., Chinese Lessons to Western Medicine. Interscience Publishers, New York, 1941.

8. Sherry, S., Eichna, L. W., and Earle, D. P., Jr., The low potassium syndrome in chronic nephritis. J. Clin. Invest. (Proc.), 1948, 27, 556.

9. Winkler, A. W., Hoff, H. E., and Smith, P. K., Electrocardiographic changes and concentration of potassium in serum following intravenous injection of potassium chloride. Am. J. Physiol., 1938, 124, 478.

10. Hoff, H. E., Smith, P. K., and Winkler, A. W., The cause of death in experimental anuria. J. Clin. Invest., 1941, 20, 607.

11. Durlacher, S. H., and Darrow, D. C., The effect of depletion of body potassium on the time of survival after nephrectomy and ureteral ligation. Am. J. Physiol., 1942, 136, 577.

12. Darrow, D. C., Harrison, H. E., and Taffel, M., Tissue electrolytes in adrenal insufficiency. $\mathrm{J}$. Biol. Chem., 1939, 130, 487.

13. Crismon, J. M., Crismon, C. S., Calabresi, M., and Darrow, D. C., Electrolyte redistribution in cat heart and skeletal muscle in potassium poisoning. Am. J. Physiol., 1943, 139, 667.

14. Smillie, W. G., Potassium poisoning in nephritis. Arch. Int. Med., 1915, 16, 330.

15. Winkler, A. W., Hoff, H. E., and Smith, P. K., The toxicity of orally administered potassium salts in renal insufficiency. J. Clin. Invest., 1941, 20, 119.

16. Keith, N. M., Burchell, H. B., and Bagenstoss, A. H., Electrocardiographic changes in uremia associated with high concentration of serum potassium. Am. Heart J., 1944, 27, 817.

17. Finch, C. A., Sawyer, C. G., and Flynn, J. M., The clinical syndrome of potassium intoxication. Am. J. Med., 1946, 1, 337.

18. Tarail, R., Electrocardiographic abnormalities in a case of uremia manifesting hyperpotassemia. Am. Heart J., 1948, 35, 665.

19. Elkinton, J. R., The volume of distribution of mannitol as a measure of the volume of extracellular fluid, with a study of the mannitol method. J. Clin. Invest., 1947, 26, 1088.

20. Elkinton, J. R., and Winkler, A. W., Transfers of intracellular potassium in experimental dehydration. J. Clin. Invest., 1944, 23, 93.

21. Elkinton, J. R., Winkler, A. W., and Danowski, T. S., Transfers of cell sodium and potassium in experimental and clinical conditions. J. Clin. Invest., 1948, 27, 74.

22. Tarail, R., and Elkinton, J. R., Potassium deficiency and the role of the kidney in its production. $\mathrm{J}$. Clin. Invest., 1949, 28, 99.

23. Tarail, $R$., The relation of abnormalities in the concentration of serum potassium to electrocardiographic disturbances. Am. J. Med., 1948, 5, 828.

24. Elkinton, J. R., Winkler, A. W., and Danowski, T. S., The importance of volume and of tonicity of the body fluids in salt depletion shock. J. Clin. Invest., 1947, 26, 1002.

25. Marchand, J. F., and Finch, C. A., Fatal spontaneous potassium intoxication in uremia. Arch. Int. Med., 1944, 73, 384.

26. Beall, D., Bywaters, E. G. L., Belsey, R. H. R., and Miles, J. A. R., A case of crush injury with renal failure. Brit. M. J., 1941, 1, 432.

27. Winkler, A. W., and Smith, P. K., The apparent volume of distribution of potassium injected intravenously. J. Biol. Chem., 1938, 124, 589.

28. Danowski, T. S., Personal communication.

29. Keith, N. M., and Osterberg, A. E., The tolerance for potassium in severe renal insufficiency : a study of ten cases. J. Clin. Invest., 1947, 26, 773.

30. Elkinton, J. R., and Taffel, M., Prolonged water deprivation in the dog. J. Clin. Invest., 1942, 21, 787.

31. Gamble, J. L., Physiological information from studies on the lifeboat ration. The Harvey Lecture Series, 1946-1947, 42, 247.

32. Goodyer, A. V. N., Peterson, E. R., and Relman, A. S., Personal communication. 
33. Berliner, R. W., Renal tubular excretion of potassium in the normal dog. Proc. Soc. Exper. Biol. \& Med., 1948, 67, 519.

34. Mudge, G. H., Foulks, J., and Gilman, A., The renal excretion of potassium. Proc. Soc. Exper. Biol. \& Med., 1948, 76, 545.

35. Earle, D. P., Jr., Taggart, J. V., and Shannon, J. A., Glomerulonephritis. A survey of the functional organization of the kidney in various stages of diffuse glomerulonephritis. J. Clin. Invest., 1944, 23, 119.

36. Winkler, A. W., Hoff, H. E., and Smith, P. K., Factors affecting the toxicity of potassium. Am. J. Physiol., 1939, 127, 430.

37. Bywaters, E. G. L., Ischemic muscle necrosis. J. A. M. A., 1944, 124, 1103.

38. Govan, C., and Weiseth, W. M., Potassium intoxication; report of an infant surviving a serum potassium level of $12.27 \mathrm{mM}$. per liter. J. Pediat., 1946, 28, 550.

39. Winkler, A. W., Smith, P. K., and Hoff, H. E., Absence of beneficial effects from injections of desoxycorticosterone acetate and of cortical adrenal extract in experimental anuria. J. Clin. Invest., 1942, 21, 419.

40. Kolff, W. J., New ways of treating uremia. J. and A. Churchill, Ltd., London, 1947.

41. Seligman, A. M., Frank, H. A., and Fine, J., Treatment of experimental uremia by means of peritoneal irrigation. J. Clin. Invest., 1946, 25, 211.

42. Maluf, N. S. R., Urea clearance by perfusion of the intact small intestine of man. J. Urol., 1948, 60, 307.

43. Sherman, H. C., Chemistry of Food and Nutrition. The Macmillan Company, New York, 1941. 